\title{
LOW BIRTH WEIGHT DWARFISM
}

\author{
BY \\ JOHN BLACK* \\ From the Royal Hospital for Sick Children, Glasgow
}

(RECEIVED FOR PUBLICATION MAY 23, 1961)

\begin{abstract}
'Every third man a pigmy!-some by rickety heads and hump backs; others by bandy legs; a third set arrested by the hand of Nature in the sixth and seventh years of their growth; a fourth in their perfect and natural state like dwarf appletrees; from the first rudiments and stamina of their existence, never meant to grow higher.' Lawrence Sterne, A Sentimental Journey.
\end{abstract}

In the course of time a variety of names have been given to Sterne's 'dwarf apple-trees': primordial dwarfism (von Hansemann, 1902), ateliosis (Gilford, 1904, 1911), microsomie essentielle (Lévi, 1910), nannosomia (or nanosomia) vera, constitutional, proportionate, genetic, and intra-uterine (Russell, 1954) dwarfism. Recently Seckel (1960) has shown that a distinct variety of low birth weight dwarfism exists, which he has called, using Virchow's (1892) original term, 'bird-headed'. All these terms appear to refer to a disorder of growth by implication present at or before birth, in which the individual is of extremely small stature, but otherwise exhibits no recognizably causative disease. For the purposes of this paper the name 'Low Birth Weight Dwarfism' is used to cover all the terms mentioned above.

It is surprising that the birth weights of such cases have received so little attention. Troen and Blumberg (1948) did, however, make a brief study of 40 cases of dwarfism and showed that their mean birth weight was significantly lower than that of normal individuals. Apart from this paper, in which many essential clinical details are lacking, there is little definite information in the literature. The continued use of eponymous terms based upon the early descriptions of dwarfism and infantilism has blurred the differences between hypopituitary dwarfism and low birth weight dwarfism. The condition described by Lorain (1871) and subsequently by Lévi (1908) appears to have been secondary to tuberculosis (Lorain), while Lévi's cases probably suffered from congenital syphilis

\footnotetext{
* Present address: Institute of Child Health, The Hospital for Sick Children, London.
}

and a cardiac lesion respectively. A secondary hypopituitarism might result from such chronic conditions, but the clinical picture is different from what we now understand as hypopituitary dwarfism. Similarly, Brissaud's (1897) cases of 'infantilisme myxoedemateux' would now be considered as juvenile myxoedema, though a similar clinical condition may result from a general hypopituitary state (Spence, 1953).

Nevertheless, Lévi (1910) gave a clear description of 'microsomie essentielle' in two families in which a dominant mode of inheritance was operative. Similar pedigrees were also reported by Gilford (1904, 1911). Gilford used the term 'ateliosis' which he divided into 'sexual' and 'asexual' forms according to the presence or absence of normal sexual maturity. He suggested that the growth defect in 'sexual ateliosis' was present from birth (low birth weight dwarfism): the asexual type appears to be equivalent to hypopituitary dwarfism in modern terminology.

In 1912 Rischbieth and Barrington made an extensive study of the genetic aspects of dwarfism using the term 'ateliosis' but without differentiating between Gilford's two types. Rössle (1924), in a comprehensive survey of growth and its disorders, produced the classification which is still in common use. He considered that 'primordial dwarfism' was distinct from all other forms of dwarfism and that the condition was always present at birth. The suggestion that low birth weight dwarfism might be due to some intra-uterine disturbance was made independently by Silver, Kiyasu, George and Deamer (1953), Russell (1954) and Silver (1959).

It is the purpose of this paper to present three cases of low birth weight dwarfism and to discuss with reference to these cases and to the literature the various clinical types which can now be distinguished.

\section{Case Reports}

Case 1 (Figs. 1 and 3 and Table 1). The first child of healthy parents, she was born on May 8, 1947, by breech 


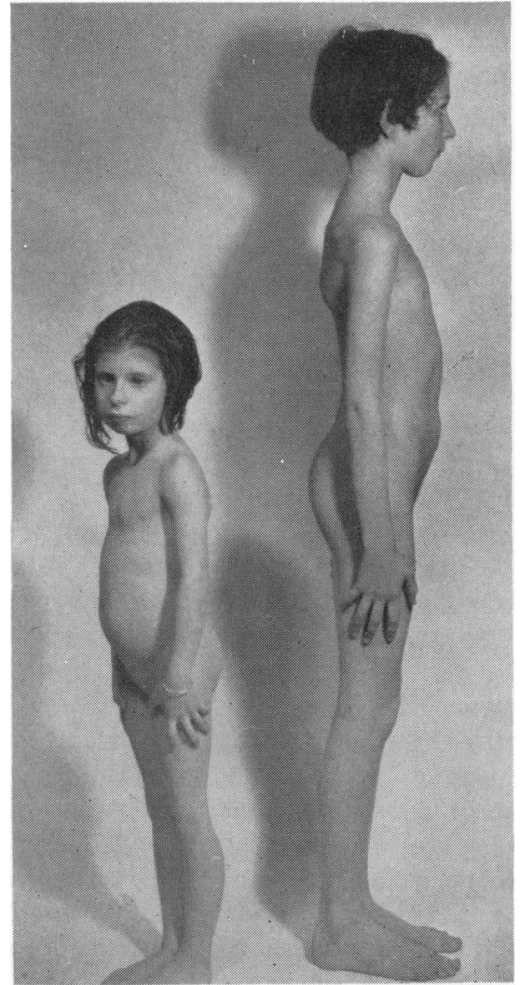

Fig. 1.-Bird-headed dwarfism: Case 1 with normal control of the same age ( 8 years 9 months).

delivery, weighing $4 \mathrm{lb} .4 \mathrm{oz} .(1.93 \mathrm{~kg}$.) after a pregnancy lasting 40 weeks. The pregnancy was normal apart from the fact that the mother thought that her abdomen had been small in proportion to the length of her pregnancy. The neonatal period was uneventful.

Her weight gain was always slow; by the age of $\mathbf{3}$ years she only weighed $15 \mathrm{lb}$. $\left(6 \cdot 82 \mathrm{~kg}\right.$.), at the age of $5 \frac{1}{2}$ years her weight was $20 \mathrm{lb}$. $(9 \cdot 26 \mathrm{~kg}$.) and her height $35 \mathrm{in}$. $(87.6 \mathrm{~cm}$.), and at 6 years her weight was $27 \mathrm{lb} .1 \mathrm{oz}$. $\left(12 \cdot 27 \mathrm{~kg}\right.$.) and height $36 \frac{1}{2} \mathrm{in}$. $(91 \cdot 4 \mathrm{~cm}$.). Her appetite was always considered to be poor. She was treated for long periods with pituitary extract by mouth without apparent effect.

There was no family history of dwarfism, but the height of the mother was $5 \mathrm{ft} .2$ in. $(157 \cdot 5 \mathrm{~cm}$.) and of the father $5 \mathrm{ft} .4$ in. $(162.6 \mathrm{~cm}$.). The age of the mother at the birth of this first child was 23 years and that of the father 29 years. There were no other children apart from the two girls described later in this paper.

At the age of 8 years and 9 months she was a small slender shy child, with a slight squint, due to hypermetropia, for which she wore glasses. Her face was small with a narrow beaky nose and small receding chin.

No treatment was given and on her return home she continued to make satisfactory progress at school. She was seen again at the age of 12 years and 4 months; during this period she had gained $6 \mathrm{in}$. $(15 \cdot 2 \mathrm{~cm}$.) in height and $14 \mathrm{lb}$. $(6 \cdot 37 \mathrm{~kg}$.) in weight. Her bodily proportions were unchanged and her head circumference had only increased by $0.5 \mathrm{in}$. $(1 \cdot 25 \mathrm{~cm}$.). At this last examination pubic hair was present but there was no other evidence of puberty.

TABLE 1

\begin{tabular}{|c|c|c|}
\hline Measurements & $\begin{array}{c}\text { First } \\
\text { Attendance }\end{array}$ & $\begin{array}{c}\text { Second } \\
\text { Attendance }\end{array}$ \\
\hline 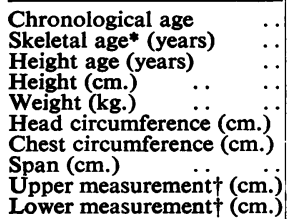 & $\begin{array}{c}8 \text { years } 9 \text { months } \\
7 \\
4 \\
99 \cdot 1 \\
11 \cdot 92 \\
45 \cdot 7 \\
45 \cdot 7 \\
96 \cdot 5 \\
53 \cdot 3 \\
48 \cdot 3\end{array}$ & $\begin{array}{c}12 \text { years } 4 \text { months } \\
9 \\
6 \\
114 \cdot 3 \\
18 \cdot 29 \\
46 \cdot 9 \\
49 \cdot 5 \\
110 \cdot 5 \\
58 \cdot 4 \\
55 \cdot 9\end{array}$ \\
\hline
\end{tabular}

* Vogt and Vickers (1938).

$\dagger$ Using symphysis pubis as middle fixed point.

Investigations. The following investigations were carried out at 8 years 9 months unless otherwise stated.

Blood Chemistry. Non-protein nitrogen, $33.8 \mathrm{mg}$. per $100 \mathrm{ml}$.; plasma chloride, $104 \mathrm{mEq}$. per litre; plasma $\mathrm{CO}_{2}, 26 \mathrm{mEq}$. per litre; blood inorganic phosphorus, $4.6 \mathrm{mg}$. per $100 \mathrm{ml}$.; serum calcium, $11 \cdot 6 \mathrm{mg}$. per $100 \mathrm{ml}$.; plasma alkaline phosphatase, 11 units per $100 \mathrm{ml}$. (King-Armstrong); whole blood cholesterol, $84 \mathrm{mg}$. per $100 \mathrm{ml}$. (normal by this method at 8 years, 90-120, and at 4 years $80-100 \mathrm{mg}$. per $100 \mathrm{ml}$. (Dutton, 1932)).

Glucose Tolerance Test (12 g. glucose orally). Fasting, $92 \mathrm{mg}$. per $100 \mathrm{ml}$; after half an hour, $160 \mathrm{mg}$. per $100 \mathrm{ml}$.; after one hour, $164 \mathrm{mg}$. per $100 \mathrm{ml}$.; after one and a half hours, $80 \mathrm{mg}$. per $100 \mathrm{ml}$.; after two hours, $56 \mathrm{mg}$. per $100 \mathrm{ml}$; ; after two and a half hours, $70 \mathrm{mg}$. per $100 \mathrm{ml}$.; and after three hours, $84 \mathrm{mg}$. per $100 \mathrm{ml}$.

URINE. Routine examination showed no abnormality; sugar chromatography revealed no abnormal sugars; amino nitrogen per 24 hours was $69 \mathrm{mg}$. (Van Slyke ninhydrin method), normal for weight, $26 \mathrm{mg}$. or $1 \mathrm{mg}$. per lb. per day; 17-ketosteroids, $0.90 \mathrm{mg}$. per 24 hours (Tompsett, 1949).

Mantoux. 1:5,000 negative. Toxoplasmosis dye test was negative and complement fixation test negative.

RADIOLOGY. The assessments of skeletal age are according to Vogt and Vickers (1938).

At the age of 8 years and 9 months the bones were slender and small; there was narrowing of both femoral necks, and bilateral rudimentary cervical ribs. The skull was small and pituitary fossa normal. The skeletal age was 7 years.

At the age of 12 years and 4 months there was narrowing of both femoral necks; the skeletal age was 9 years.

Psychological RePORT. This was carried out at the age of 8 years and 9 months. She was tested on the Terman-Merrill (form L) scale and on the Goodenough 'Draw-a-man' test. In the former, her mental age was given as 6 years (I.Q. 74), but this was considered to be 
a considerable underestimate as her performance seemed to be inhibited by lack of confidence. The Goodenough test gave a mental age of 8 to 9 years.

Comment. This child was of very slender build with a bird-like face. There was no abnormality of her blood chemistry, but her glucose tolerance curve showed a moderate reactive hypoglycaemia. Estimation of her 17-ketosteroid output gave a value perhaps more in conformity with her 'height age' rather than her chronological age. Her daily output of amino acids was higher than would have been expected on a weight basis, but this may be related to a greater turn-over of amino acids than would have been expected for the actual weight, a problem which was discussed in part by Ranke and von Voit (1886). The skeletal age was markedly delayed at both examinations, but apart from this there was no evidence of hypopituitarism. The appearance of pubic hair at the age of 12 years and 4 months is against hypopituitarism, though at this time there was no breast development. Psychological testing at 8 years and 9 months showed social immaturity rather than intellectual inadequacy.

Case 2 (Figs. 2 and 3 and Table 2). This child, the sister of Case 1, was born on February 22, 1949, by breech delivery at full term, weighing $3 \mathrm{lb} .2 \mathrm{oz}$. $(1 \cdot 42 \mathrm{~kg}$.). The pregnancy had been uneventful, though the mother had noticed that she was 'small' all through her pregnancy. At birth she was 'slow to cry', but was not cyanosed and did not become jaundiced. By the age of $8 \frac{1}{2}$ weeks she weighed $5 \mathrm{lb}$. $(2 \cdot 27 \mathrm{~kg}$.) and at 1 year $10 \mathrm{lb}$. $(4 \cdot 54 \mathrm{~kg}$.); she sat up at 1 year, walked at 1 year 3 months and spoke at 2 years. She was treated for a short period with whole pituitary gland orally without effect.

She was admitted to the Royal Hospital for Sick Children with her sister on February 22, 1956, for investigation.

She had a similar facial appearance to her sister and was of very slender build.

TABLE 2

\begin{tabular}{|c|c|c|c|}
\hline Measurements & & $\begin{array}{c}\text { First } \\
\text { Attendance }\end{array}$ & $\begin{array}{c}\text { Second } \\
\text { Attendance }\end{array}$ \\
\hline $\begin{array}{l}\text { Chronological age (years) } \\
\text { Skeletal age* (years) } \quad . \\
\text { Height age (years) } \quad . \\
\text { Height (cm.) } \quad . \\
\text { Weight (kg.) } \quad \ldots \\
\text { Head circumference (cm.) } \\
\text { Chest circumference (cm.) } \\
\text { Span (cm.) } \quad . \\
\text { Upper measurement }+ \text { (cm.) } \\
\text { Lower measurement }+ \text { (cm.) }\end{array}$ & \begin{tabular}{l|}
$\cdots$ \\
$\cdots$ \\
$\cdots$ \\
$\cdots$ \\
$\cdots$ \\
$\cdots$ \\
$\cdots$ \\
$\cdots$
\end{tabular} & $\begin{array}{l}7 \\
4 \cdot 5 \\
3 \\
92 \cdot 7 \\
10 \cdot 00 \\
44 \cdot 4 \\
43 \cdot 2 \\
87 \cdot 6 \\
48 \cdot 3 \\
44 \cdot 4\end{array}$ & $\begin{array}{c}10 \\
7 \\
5 \\
107 \cdot 9 \\
14 \cdot 49 \\
45 \cdot 2 \\
45 \cdot 7 \\
104 \cdot 1 \\
54 \cdot 6 \\
53 \cdot 3\end{array}$ \\
\hline
\end{tabular}

- Vogt and Vickers (1938).

† Using symphysis pubis as middle fixed point.

Investigations. The following investigations were carried out at the age of 7 years unless otherwise stated.

Blood Chemistry. Non-protein nitrogen, $37.5 \mathrm{mg}$. per $100 \mathrm{ml}$.; plasma chloride, $102 \mathrm{mEq}$. per litre; plasma $\mathrm{CO}_{2}, 25 \mathrm{mEq}$. per litre; blood inorganic phosphorus,

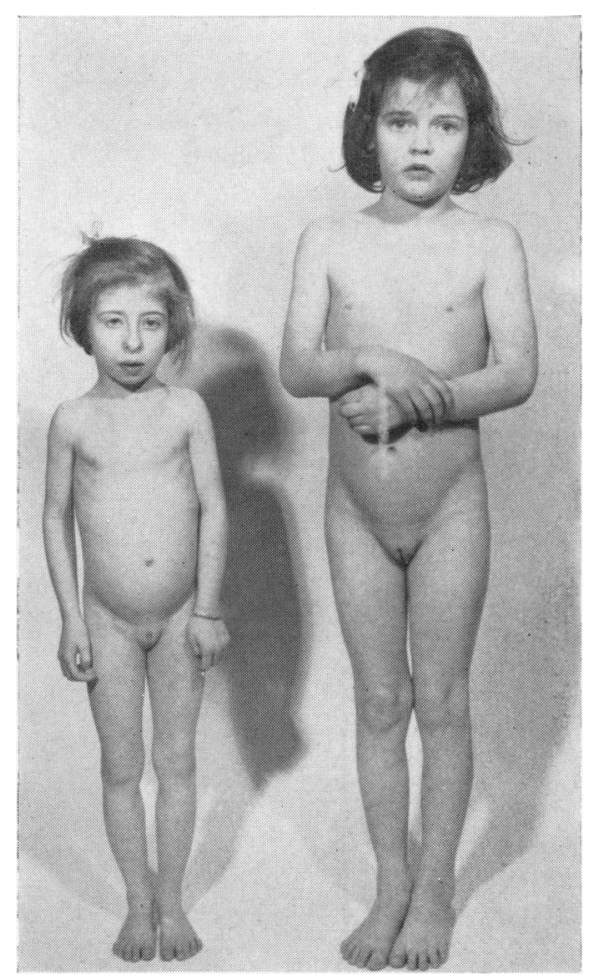

Fig. 2.-Bird-headed dwarfism: Case 2 with normal control of the same age ( 7 years).

$4.7 \mathrm{mg}$. per $100 \mathrm{ml}$.; serum calcium, $11 \cdot 2 \mathrm{mg}$. per $100 \mathrm{ml}$.; plasma alkaline phosphatase, 10 units per $100 \mathrm{ml}$. (KingArmstrong); whole blood cholesterol, $75 \mathrm{mg}$. per $100 \mathrm{ml}$. (normal at 7 years, 70-100; and at 3 years, $60-90 \mathrm{mg}$. per $100 \mathrm{ml}$. (Dutton, 1932)).

Glucose Tolerance Test (12 g. of glucose given). Fasting, $42 \mathrm{mg}$. per $100 \mathrm{ml}$. (no symptoms); after half an hour, $135 \mathrm{mg}$. per $100 \mathrm{ml}$.; after one hour, $88 \mathrm{mg}$. per $100 \mathrm{ml}$.; after one and a half hours, $58 \mathrm{mg}$. per $100 \mathrm{ml}$; after two hours, $23 \mathrm{mg}$. per $100 \mathrm{ml}$. (no symptoms).

A repeat test $(12 \mathrm{~g}$. of glucose) gave the following results: Fasting, $68 \mathrm{mg}$. per $100 \mathrm{ml}$.; after half an hour, $72 \mathrm{mg}$. per $100 \mathrm{ml}$; ; after one hour, $106 \mathrm{mg}$. per $100 \mathrm{ml}$.; after one and a half hours, $56 \mathrm{mg}$. per $100 \mathrm{ml}$; after two hours, $48 \mathrm{mg}$. per $100 \mathrm{ml}$.; after two and a half hours, $58 \mathrm{mg}$. per $100 \mathrm{ml}$.; and after three hours, $44 \mathrm{mg}$. per $100 \mathrm{ml}$.

URINE. Routine examination showed no abnormality; sugar chromatography revealed no abnormal sugars; amino acid nitrogen output per 24 hours was $83 \mathrm{mg}$. (raised) (Van Slyke ninhydrin method); 17-ketosteroids, 0.61 mg. per 24 hours (Tompsett, 1949); a level more in keeping with her 'height age' than her chronological age.

Mantoux. 1:5,000 negative. Toxoplasmosis dye test was negative and complement fixation test negative. 


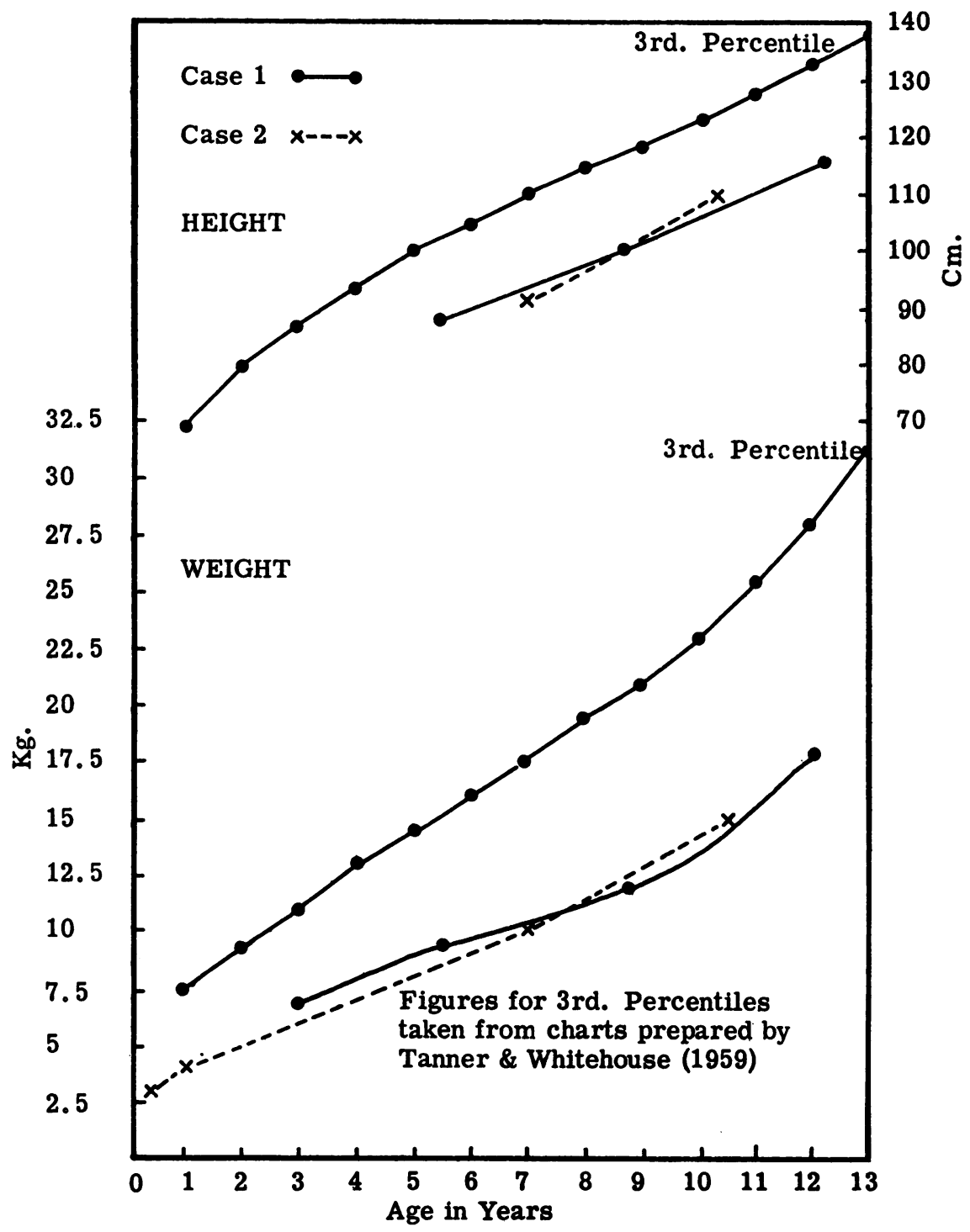

Fig. 3.-Progress in height and weight of Cases 1 and 2 in relation to 3rd percentile.

RADIOLOGY. The assessments of skeletal age are according to Vogt and Vickers (1938). At the age of 7 years the skull was small and pituitary fossa normal. At the age of 10 years and 6 months there was narrowing of both femoral necks (Fig. 4). The skeletal age was 7 years.

Psychological Report. Psychological testing was carried out at the age of 7 years. She was tested on the Terman-Merrill form L and Goodenough 'Draw-a-man' test. On the former she had an I.Q. of 79, but the Goodenough test gave a mental age of 6 to 9 years.
There was evidence of lack of confidence inhibiting her performance.

Comment. This child was strikingly similar to her sister in every way except for a low fasting blood sugar and extreme reactive hypoglycaemia in her first tolerance curve.

Case 3 (Fig. 5 and Table 3). This girl (M.C.), the firstborn of twins, was delivered $4 \frac{1}{2}$ weeks before term on December 14, 1957, weighing $3 \mathrm{lb} .1 \mathrm{oz}$. $(1 \cdot 39 \mathrm{~kg}$.). The 
TABLE 3

\begin{tabular}{|c|c|c|c|}
\hline Measurements & & $\begin{array}{l}\text { Case } 3 \\
\text { (M.C.) }\end{array}$ & $\begin{array}{c}\text { Normal Twin } \\
\text { (H.C.) }\end{array}$ \\
\hline $\begin{array}{l}\text { Chronological age (years) } \\
\text { Skeletal age* (months) } \\
\text { Height age (months) } \ldots \\
\text { Height (cm.) .. } \\
\text { Weight (kg.) .. } \\
\text { Head circumference (cm.) } \\
\text { Chest circumference (cm.) } \\
\text { Span (cm.) . } \\
\text { Upper measurement } \text { (cm.) }_{\text {Lower measurement } \dagger \text { (cm.) }}\end{array}$ & $\begin{array}{l}\cdots \\
\cdots \\
\cdots \\
\cdots\end{array}$ & $\begin{array}{l}1 \cdot 5 \\
3-6 \\
3 \\
61 \cdot 0 \\
4 \cdot 95 \\
44 \cdot 5 \\
38 \cdot 0 \\
62 \cdot 0 \\
39 \cdot 0 \\
22 \cdot 0\end{array}$ & \begin{tabular}{|c|}
$1 \cdot 5$ \\
18 \\
24 \\
$82 \cdot 5$ \\
(between 75th and \\
90 th percentile) \\
$10 \cdot 40$ \\
$46 \cdot 0$ \\
$50 \cdot 0$ \\
$85 \cdot 5$ \\
$46 \cdot 0$ \\
$36 \cdot 5$
\end{tabular} \\
\hline
\end{tabular}

- Vogt and Vickers (1938).

$\dagger$ Using symphysis pubis as middle fixed point.

delivery of the second twin was obstructed by the placenta of the first which had partly separated and was protruding through the os. The second twin, who weighed $5 \mathrm{lb}$. $13 \frac{1}{2} \mathrm{oz}$. $(2 \cdot 66 \mathrm{~kg}$.), was extracted as a breech under general anaesthesia. The first placenta was 'infarcted' with a velamentous insertion, but the second placenta appeared to be normal. The placentae were quite separate, though the chorions were united; the twins were considered to be binovular. There were five other living children born before the twins, all of normal birth weight. One child, born in 1947, birth weight $6 \mathrm{lb} .4 \mathrm{oz}$. (2.74 kg.), died of 'convulsions' at the age of 3 months, and in 1951 there was a miscarriage at $3 \frac{1}{2}$ months gestation.

Progress. M.C. appeared active at birth while the second twin (H.C.) was said to be 'slightly shocked', but subsequently progressed quite normally. M.C., however, gained weight slowly and was discharged from hospital after 10 weeks, weighing $5 \mathrm{lb} .7 \mathrm{oz}$. $(2 \cdot 47 \mathrm{~kg}$.).

By the age of 4 months H.C. weighed $12 \mathrm{lb}$. $6 \mathrm{oz}$. $(5.63 \mathrm{~kg}$.), while M.C. had only gained $3 \mathrm{oz}$. (0.085 kg.) since her discharge from the maternity hospital. She was therefore admitted to hospital for investigation. She remained in hospital for eight weeks, gaining weight slowly up to $7 \mathrm{lb}$. $3 \mathrm{oz}$. $(3.27 \mathrm{~kg}$.). The only abnormalities detected were slightly raised blood urea and a faint systolic murmur audible down the left side of the sternum, but at the age of 10 months the murmur was no longer audible (for investigations, see below). At the age of 1 year she was again admitted to hospital with the diagnosis of pneumonia.

She was finally admitted to the Royal Hospital for Sick Children, Glasgow, at the age of $1 \frac{1}{2}$ years for further investigation.

Development. She sat up at 8 months and crawled at 1 year. At 1 year and 4 months she was able to stand with support. At the age of $1 \frac{1}{2}$ years, though she appeared alert and active, she was unable to speak at all, though she made babbling and imitative noises.

Investigations. The following investigations were carried out at first admission when she was 4 months.

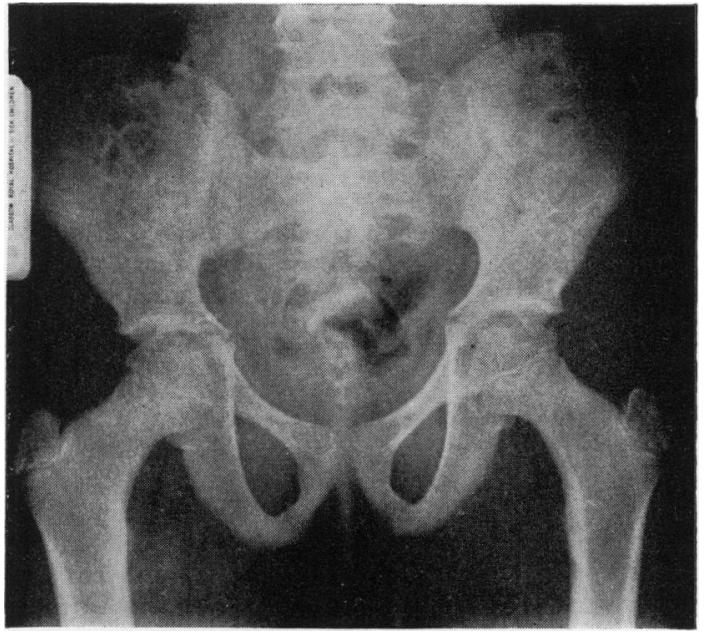

FIG. 4.-Radiograph of hips of Case 2, showing narrowing of femoral necks.

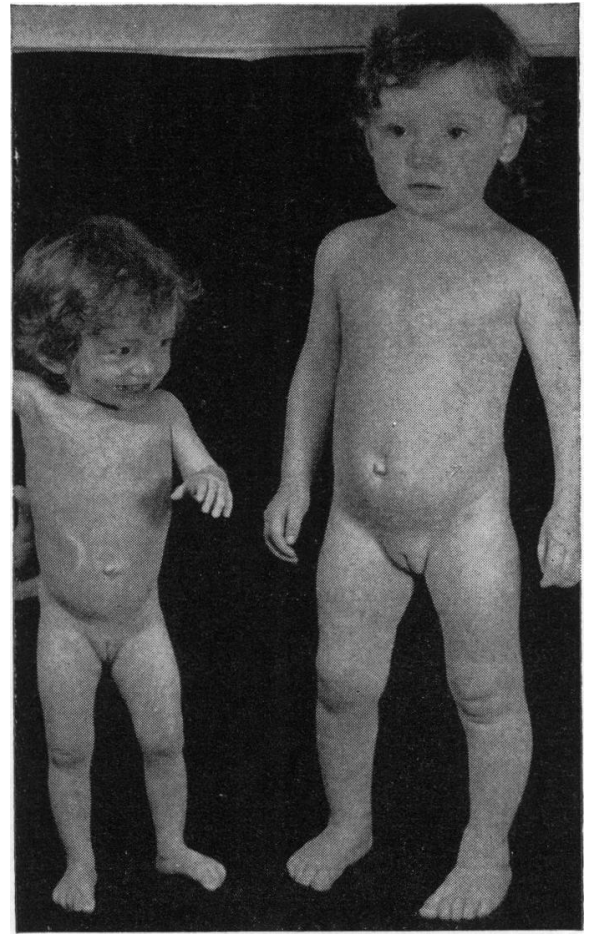

Fig. 5.-Dwarfed twin: Case 3 with normal twin at the age of 18 months. 
The blood urea was $53 \mathrm{mg}$. per $100 \mathrm{ml}$.

The urine was normal to routine testing. Chromatography revealed a normal amino acid pattern, and glucose and xylose were present in normal amounts.

The stool had no pathogens on culture. Microscopy showed no abnormal constituents. Tryptic digestion was up to a dilution of $1: 6,000$.

A radiograph of the chest revealed increased bronchovascular markings in right upper lobe; there was no abnormality of the abdomen, and no abnormality of the wrist apart from the absence of the centres of capitate and hamate bones.

On her second admission at the age of 1 year further investigations were undertaken.

A full blood count was normal; the cerebrospinal fluid revealed 2 cells per c.mm.; protein, $30 \mathrm{mg}$. per $100 \mathrm{ml}$.; chloride, $128 \mathrm{mEq}$. per litre, and sugar, $46 \mathrm{mg}$. per $100 \mathrm{ml}$.

Radiographs of the chest and skull were normal; there were no centres for capitate and hamate bones in the wrist.

She was admitted for the third time at the age of 18 months.

Blood Chemistry. Serum sodium, $145 \mathrm{mEq}$. per litre; serum potassium, 5.6 mEq. per litre; plasma chloride, $100 \mathrm{mEq}$. per litre; plasma $\mathrm{CO}_{2}, 22 \mathrm{mEq}$. per litre; calcium, $11 \cdot 2 \mathrm{mg}$. per $100 \mathrm{ml}$.; blood urea, $55 \mathrm{mg}$. per $100 \mathrm{ml}$., and serum cholesterol, $370 \mathrm{mg}$. per $100 \mathrm{ml}$. (normal 150-200 mg. per $100 \mathrm{ml}$. (Macintyre and Ralston, 1954)).

Glucose Tolerance Test (5 g. glucose given). Fasting, $49 \mathrm{mg}$. per $100 \mathrm{ml}$; after half an hour, $87 \mathrm{mg}$. per $100 \mathrm{ml}$.; after one hour, $91 \mathrm{mg}$. per $100 \mathrm{ml}$.; after one and a half hours, $56 \mathrm{mg}$. per $100 \mathrm{ml}$.; after two hours, $59 \mathrm{mg}$. per $100 \mathrm{ml}$; and after two and a half hours, $67 \mathrm{mg}$. per $100 \mathrm{ml}$.

URINE. 17-ketosteroids per 24 hours were $0.33 \mathrm{mg}$. and $0.35 \mathrm{mg}$. on two successive days (Tompsett, 1949). This is within the normal for her 'height age' or her chronological age.

RADIOLOGY. The long bones were small and there was some osteoporosis, with thin cortex and deficient trabeculation. Skull and pituitary fossa were normal, skeletal age between 3 and 6 months. Assessment of skeletal age was according to Vogt and Vickers (1938).

Comparison with other twin revealed the following:

M.C.

Blood group: A. Rh negative Eye colour: Blue

Hair colour: Light reddish

Comment. The main clinical features of this child were her very low intelligence and her extreme degree of dwarfing, which was even more marked than in Cases 1 and 2 . In this child the rather flat glucose tolerance curve suggested adrenal insufficiency, perhaps secondary to hypopituitarism, and this was confirmed by the very retarded skeletal development; the high blood urea was an unusual feature and remains unexplained, in the absence of any demonstrable renal lesion or electrolyte disturbance.
In general, the findings were similar to the case, also a twin, described by LoPresti, St. Martin and Pascual (1952).

\section{Discussion}

Definition. Though a low birth weight is essential for the diagnosis of this condition, a definition by length would be preferable. However, the length at birth is not always measured and is seldom recollected by parents. It is necessary to take into account the fact that many infants, fully mature by dates, weigh less than $5 \frac{1}{2} \mathrm{lb}$. $(2 \cdot 50 \mathrm{~kg}$. $)$, but Drillien (1957) has shown that very few of these weigh less than $4 \frac{1}{2} \mathrm{lb}$. $(2.05 \mathrm{~kg}$.). A full-term baby weighing less than $4 \frac{1}{2} \mathrm{lb}$. may therefore be considered to be abnormally small. Estimations of the length of pregnancy are accepted to be inaccurate by about two weeks in either direction and it therefore seems reasonable to include as mature infants born at or after 38 weeks. There is also the possibility that low birth weight itself, irrespective of the length of pregnancy, might produce permanent dwarfism, but Drillien (1958) has shown that though premature babies of very low birth weight (i.e. $3 \mathrm{lb} .(1 \cdot 36 \mathrm{~kg}$.) or less) seldom attain the mean values for height and weight by the age of 9 years (which was the oldest group in Drillien's series), only a few fall below the 3rd percentile and would be considered as dwarfed. Similar results were obtained in a followup of very small prematures by Dann, Levine and New (1958). Not all low birth weight dwarfs are necessarily born at term; M.C. (Case 3, birth weight $3 \mathrm{lb} .1 \mathrm{oz}$. (1.39 kg.)) one of twins, was born at $35 \frac{1}{2}$ weeks, but the other twin, who weighed $5 \mathrm{lb}$. $13 \frac{1}{2}$ oz. $(2 \cdot 66 \mathrm{~kg}$.) can fairly be considered as an adequate control.

The following diagnostic criteria must therefore be fulfilled before accepting a diagnosis of low birth weight dwarfism with the qualifications mentioned above.

(1) Birth weight of less than $4 \frac{1}{2} \mathrm{lb} .(2.05 \mathrm{~kg}$.).

(2) Length of gestation of not less than 38 weeks (with the qualification for twins mentioned above).

(3) Height below the 3rd percentile throughout period of observation.

(4) No gross physical disproportion.

Clinical Types. Much of the literature on dwarfism has been concerned with rather sterile discussions about the existence or non-existence of 'miniature' individuals with bodily proportions identical with those of a normal person of the same age. In practice most comparisons have been made by means of the 'height-age' or 'konstitutionelle Alter' 
TABLE 4

CLASSIFICATION OF LOW BIRTH WEIGHT DWARFISM

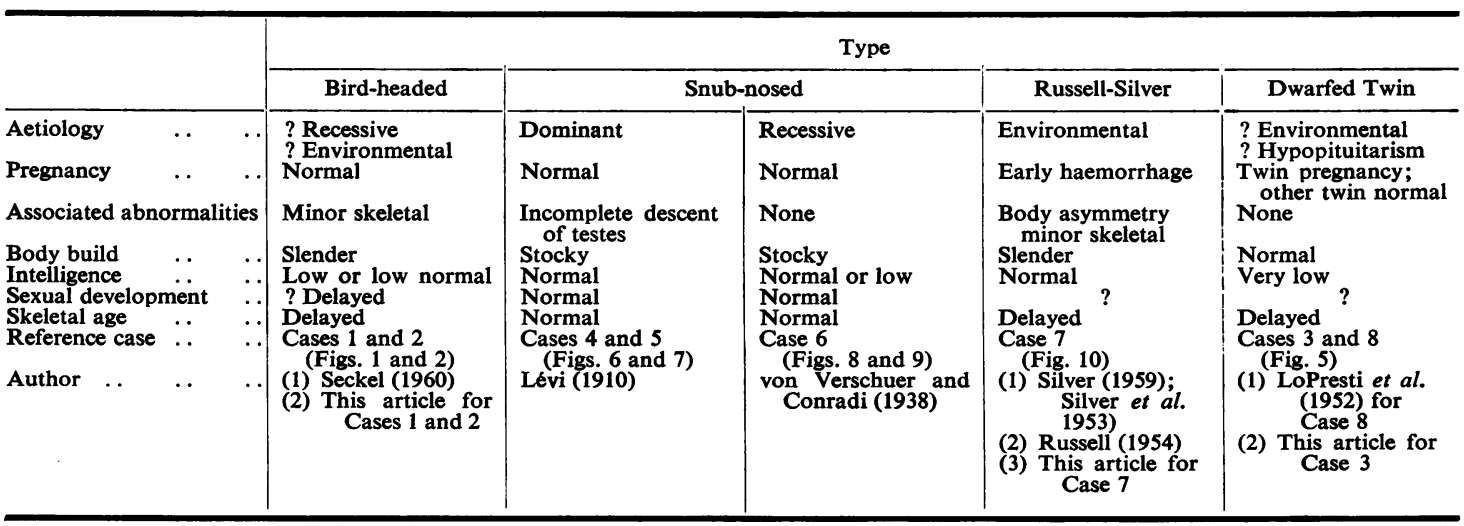

(Kirchhoff, Lehmann and Schaefer, 1954), a method in which the dwarf's measurements are compared with those of a normal child with the same height as the dwarf. As ordinarily used, this method has the considerable disadvantage that the 'standard' child does not have the same proportions as a dwarf of the same height but many years older. In order to avoid this difficulty various ratios have been proposed (head circumference : height, arm span : height, upper measurement : lower measurement, etc.) which may have statistical validity when comparing one large group with another. But when such ratios are applied to individuals it is found that the standard deviations of the component measurements are great enough to cause considerable variations in the supposedly constant ratios. Another difficulty in the use of sets of standard ratios is the fact that small errors in both measurements may produce a large error in the ratio.

From a clinical point of view the object is to obtain such information from body measurements as will help one to place a dwarf in a particular category within a general classification. For this purpose the only reliable form of comparison is still the 'height-age' method, using only measurements whose standard deviations from the mean are known. In practice this allows the use of the height as determining the appropriate 'height-age' standard, and the head circumference and arm span for comparison. There appear to be no data for the standard deviations from the means for upper and lower measurements, and the weight and chest circumference are likely to be invalidated by variations in body fat. It remains, therefore, to see whether the deviations from the mean values of head circumference and arm span show any consistent trends in the four types of low birth weight dwarfism considered here (Tables 4 and 5).

I. Low Birth Weight Dwarfism: Bird-headed Type (Cases 1 and 2; Figs. 1 and 2). Seckel has shown that the bird-headed dwarfs have a characteristic beaky nose and receding jaw. They are of very slender build. Their intelligence is low or low normal and appears to decline as they get older; possibly this is related to the small absolute size of their skulls, another characteristic feature. Skeletal development tends to be retarded, more so in the regions where there are congenital abnormalities of the bones. At present it is not possible to say whether sexual development proceeds normally or is delayed.

Seckel considers that bird-headed dwarfism is inherited as a recessive, but the documentation of many of the older cases in the literature is incomplete. It may, however, be significant that in Seckel's Case 1 the paternal grandparents were first cousins.

In the two cases described here, the face and clinical features fit well with Seckel's description. The occurrence of two cases in one sibship is very suggestive of a recessively inherited disorder, particularly in view of the small stature of the parents, but a recurring abnormality of the intra-uterine environment cannot be excluded. In both cases there was a curious narrowing of the femoral necks (Fig. 4) and in Case 1 bilateral cervical ribs were present. The appearance of pubic hair in Case 1 at the age of 12 years, without other evidence of puberty cannot be taken to indicate any specific endocrine condition, as this may occur in normal girls and also in ovarian agenesis (Wilkins, 1957). 
MEASUREMENTS OF CASES IN

, Bird-headed

\begin{tabular}{|c|c|c|c|c|c|c|c|c|c|}
\hline Case no. & . & $\cdots$ & . & $\cdots$ & $\cdots$ & $\cdots$ & $1 *$ & $2 *$ & $4+$ \\
\hline $\begin{array}{l}\text { Sex . } \\
\text { Birth weight (kg.) } \\
\text { Age at examination } \\
\text { Height (cm.) .. } \\
\text { Height age .. } \\
\text { Skeletal age . } \\
\text { Head circumference } \\
\text { Mean for heigh } \\
\text { Mean for actua } \\
\text { Arm span (cm.) } \\
\text { Mean for beigh } \\
\text { Reference .. }\end{array}$ & $\begin{array}{l}\ldots \\
\ldots \\
\ldots \\
\cdots \\
\text { (cm.) } \\
\text { t age (c } \\
\text { age (c } \\
\therefore \\
\text { age (c } \\
\ldots\end{array}$ & $\begin{array}{l}\cdots \\
\ldots \\
\cdots \\
\cdots \\
\cdots \\
\cdots \\
\text { cm.) } \\
\cdots \\
\text { cm.) } \\
\cdots\end{array}$ & $\begin{array}{l}\cdots \\
\cdots \\
\cdots \\
\cdots \\
\cdots \\
\cdots \\
\cdots \\
\cdots \\
\cdots\end{array}$ & $\begin{array}{l}\cdots \\
\cdots \\
\cdots \\
\cdots \\
\cdots \\
\cdots \\
\cdots \\
\cdots \\
\cdots\end{array}$ & $\begin{array}{l}\cdots \\
\cdots \\
\cdots \\
\cdots \\
\cdots \\
\cdots \\
\cdots \\
\cdots \\
\cdots\end{array}$ & $\begin{array}{l}\cdots \\
\cdots \\
\cdots \\
\cdots \\
\cdots \\
\cdots \\
\cdots \\
\cdots \\
\cdots\end{array}$ & $\begin{array}{c}\text { Femake } \\
1 \cdot 93 \\
12 \text { years } 4 \text { months } \\
114 \\
6 \text { years } \\
9 \text { years } \\
47 \\
51 \cdot 25(-2 \text { S.D.: } 48 \cdot 17) \\
53 \cdot 33(-2 \text { S.D.: } 50 \cdot 77) \\
113 \cdot 7(-2 \text { S.D.: } 100 \cdot 38) \\
\text { This paper }\end{array}$ & $\begin{array}{c}\text { Female } \\
1.42 \\
10 \text { years } 6 \text { months } \\
108 \\
5 \text { years } \\
7 \text { years } \\
45 \\
50 \cdot 50(-2 \text { S.D.: } 47 \cdot 82) \\
52 \cdot 23(-2 \text { S.D.: } 49 \cdot 47) \\
104.6(-2 \text { S.D.: } 96 \cdot 92) \\
\text { This paper }\end{array}$ & $\begin{array}{c}\text { Male } \\
\text { Low } \\
50 \text { years } \\
106 \\
5 \text { years } \\
\text { Normal } \\
50 \\
51 \cdot 15(-2 \text { S.D.: } 48 \cdot \\
56 \cdot 62+(-2 \text { S.D.: } 53 \cdot \\
\text { Levi } \overline{(1910)}\end{array}$ \\
\hline
\end{tabular}

- Cases 1 and 2: sisters.

+ Cases 4 and 5: father and son.

From the clinical features described above and from the various investigations performed on Cases 1 and 2 , it seems unlikely that hypopituitarism is the cause of the growth lag. The facial appearance

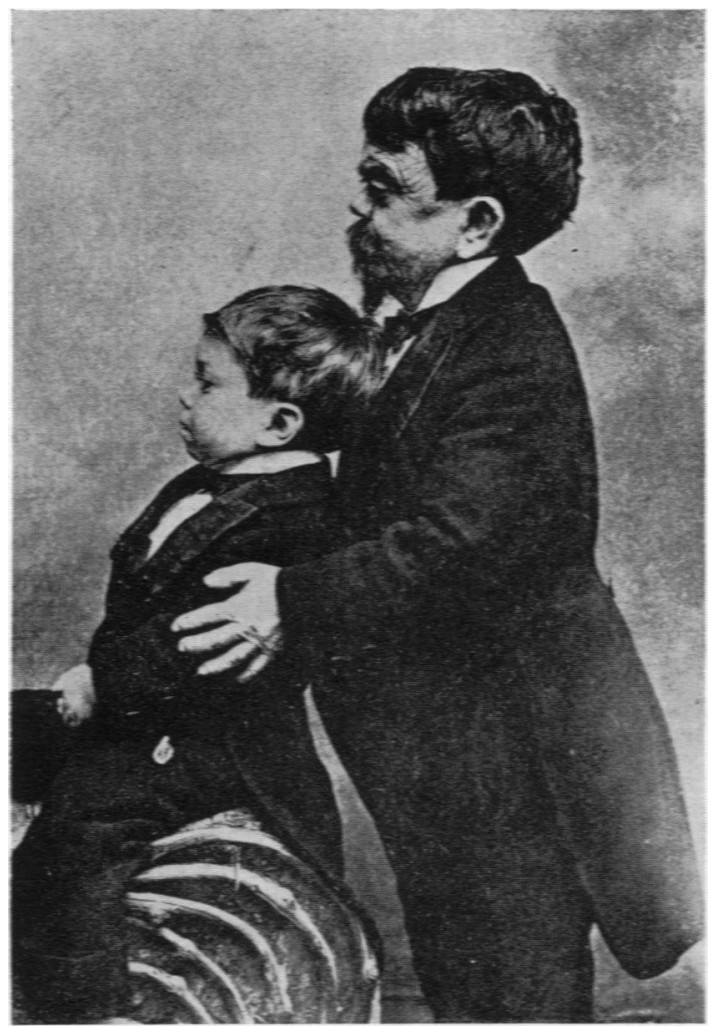

FiG. 6.-Snub-nosed dwarfism; dominant type: Cases 4 and 5 from Lévi (1910).
\$ Mean values for $17 \frac{1}{\text { years. }}$

\$ Values from Falkner (1958) extrapolated when necessary; all other via

makes the head look unduly small, but Seckel has concluded that the head circumference is reduced in the same proportion as the height. From Table 5 it can be seen that in Cases 1 and 2 the head circumference is smaller than -2 S.D. from the mean for the height-age standard, and this seems to be characteristic of bird-headed dwarfism. The reduction in arm span, compared to the height-age standard is, however, probably not significant.

II. Low Birth Weight Dwarfism: Snub-nosed Type (Cases 4, 5 and 6; Figs 6, 7,8 and 9; for summary of case histories see appendix). There is at present no satisfactory term to describe these dwarfs: 'snub-nosed' is not really accurate as it is the bridge of the nose which is flat, while the tip is normal. The typical appearance is well shown in Figs. 6 and 8.

In this type of dwarfism the general appearance is stocky, the intelligence is normal in the dominant type and sometimes low in the recessive type. Sexual maturation occurs at the normal age or may be slightly delayed and skeletal abnormalities are absent. Partially (Case 4) or completely (Case 5) undescended testes seem to be relatively common. In most of the families described a dominant mode of transmission is found (Gilford, 1904, 1911; Lévi, 1910; Rössle, 1924), but in 1938 von Verschuer and Conradi described a family in which six snub-nosed dwarfs (three males and three females) occurred in three sibships in three generations, with consanguinity in the parentage of one of the sibships (maternal great grandfather and paternal grandfather were brothers).

This type of dwarfism has been termed 'normocephalic', but in the three cases (Cases 4, 5 and 6) quoted here, the head circumference was less than 
LE 5

ATION TO HEIGHT-AGE STANDARDS

\begin{tabular}{|c|c|c|c|c|}
\hline \multicolumn{2}{|l|}{ Snub-nosed Types } & \multirow[t]{2}{*}{ Russell-Silver } & \multirow{2}{*}{\multicolumn{2}{|c|}{ Dwarfed Twin }} \\
\hline ant & Recessive & & & \\
\hline $5+$ & 6 & 7 & 3 & 8 \\
\hline $\begin{array}{c}\text { Male } \\
\text { Low } \\
12 \text { years } 6 \text { months } \\
77 \\
15 \text { months } \\
\text { Normal } \\
46 \\
47.55(-2 \text { S.D.: } 45 \cdot 00) \\
53 \cdot 89(-2 \text { S.D.: } 52 \cdot 13) \\
\text { Lévi }(1910)\end{array}$ & $\begin{array}{c}\text { Female } \\
\text { Low } \\
36 \text { years } \\
125 \\
8 \text { years } 6 \text { months } \\
\text { Normal } \\
49 \cdot 6 \\
51 \cdot 52(-2 \text { S.D.: } 49 \cdot 06) \\
54 \cdot 85 \div(-2 \text { S.D.: } 53 \cdot 09) \\
- \\
\text { - } \\
\text { von Verschuer and } \\
\text { Conradi (1938) }\end{array}$ & $\begin{array}{c}\text { Male } \\
1 \cdot 37 \\
5 \text { years } 7 \text { months } \\
94 \\
3 \text { years } \\
3-5 \text { years } \\
50 \cdot 5 \\
50 \cdot 45(-2 \text { S.D.: } 53 \cdot 0) \\
51 \cdot 15(-2 \text { S.D.: } 49 \cdot 31) \\
87 \\
91 \cdot 9 \$ 5 \text { (no data for S.D.) } \\
\text { Russell: personal com- } \\
\text { munication }\end{array}$ & $\begin{array}{c}\text { Female } \\
1 \cdot 39 \text { (35t weeks) } \\
1 \text { year } 6 \text { months } \\
60 \\
3 \text { months } \$ \\
3-6 \text { months } \\
39 \cdot 75(-2 \text { S.D.: } 41 \cdot 9) \\
47 \cdot 0(-2 \text { S.D.: } 44 \cdot 8) \\
63 \text {. } \\
57 \cdot 05 \$ \text { (no data for S.D.) } \\
\text { This paper }\end{array}$ & $\begin{array}{c}\text { Female } \\
1 \cdot 31 \\
1 \text { year } 9 \text { months } \\
55 \\
2 \text { months } \$ \\
\text { 'Delayed' } \\
43 \\
37 \cdot 95(+2 \text { S.D.: } 40 \cdot 1) \\
47 \cdot 45(-2 \text { S.D.: } 45 \cdot 25) \\
- \\
\text { LoPresti et al. (1952) }\end{array}$ \\
\hline
\end{tabular}

§乌 Average figures from Wilkins (1957).

from Provis and Ellis (1955).

see Appendix; see also Fig. 5). In 1952 LoPresti

the mean values for chronological age (taking the values for $17 \frac{1}{2}$ years to be the same as adult figures) but larger than that of the bird-headed dwarfs when compared with their 'height-age' standard (see Table 5).

III. Low Birth Weight Dwarfism Attributed to Disturbance in Early Pregnancy (Russell-Silver type; Case 7; for summary of case history see Appendix, also Fig. 10). The characteristic findings in this condition are a difference in size between the two sides of the body, together with other minor congenital abnormalities such as syndactyly and hypospadias. The facial appearance is characteristic with an underdevelopment of the lower jaw, so that the head looks relatively large. This appearance is, however, misleading as the head appears to be roughly the size to be expected from the heightage. The skeletal age is retarded and the intelligence is normal. In spite of intensive investigations, no evidence of any endocrine basis to this disorder has been discovered, though the finding by Silver et al. (1953) and Silver (1959) of an increased level of gonadotrophins in some of their cases suggested a gonadal deficiency. From the data at present available, it is not possible to say whether puberty is reached at a normal age. The history of an early placental disturbance which is particularly striking in Russell's series, combined with such fundamental abnormalities as an asymmetry of the body, suggests also an early disorder of development which might well be associated with a distortion of the subsequent growth pattern.

IV. Low Birth Weight Dwarfism Attributed to Disturbance in Late Pregnancy (dwarfed-twin type; Cases 3 and 8 ; for summary of history of Case 8 et al. described a 21-month-old girl with a birth weight of $1.31 \mathrm{~kg}$. who was one of twins, the other being normal (birth weight $2.42 \mathrm{~kg}$.). In the dwarfed twin the head appeared relatively large and the intelligence was extremely low. On the basis of the very delayed skeletal development and increased sensitivity to insulin it was concluded that hypopituitarism, with some cerebral damage, was the most likely diagnosis even though the dwarfism

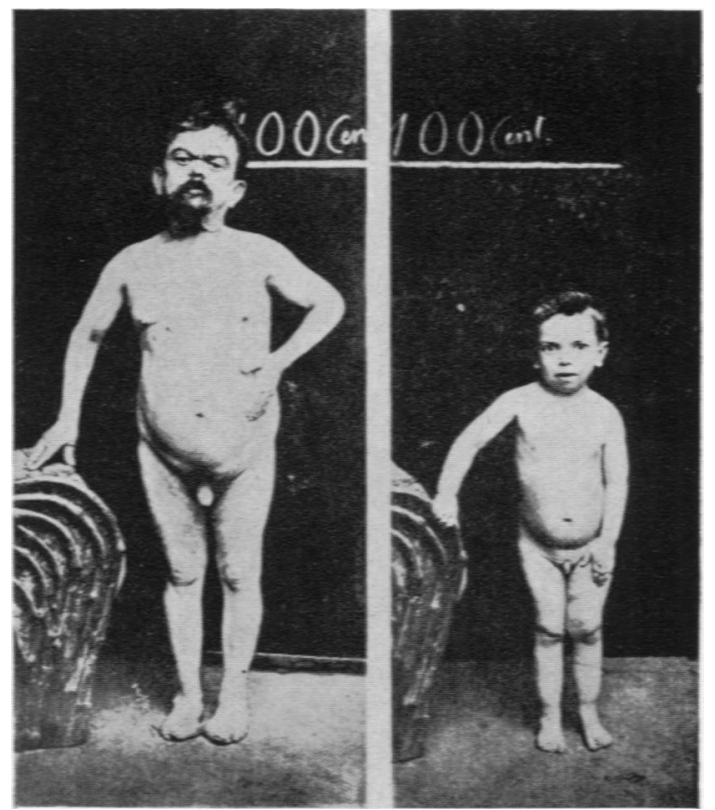

Fig. 7.-Snub-nosed dwarfism; dominant type: Cases 4 and 5 from Lévi (1910). 


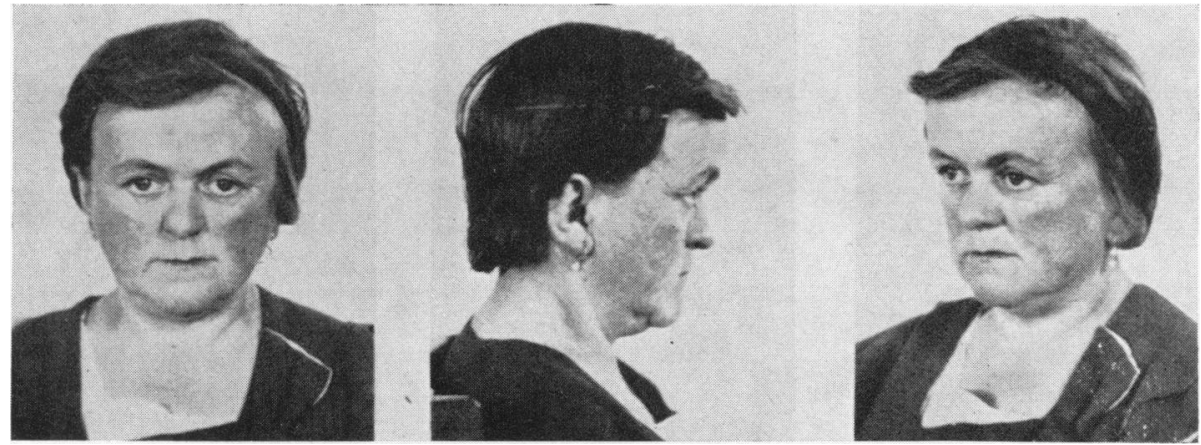

Fig. 8.-Snub-nosed dwarfism; recessive type: Case 6 from Verschuer and Conradi (1938).

had been present since birth. Case 3 described here shows very similar features. It can be seen from Table 5 that comparison with their height-age standards shows that in both cases the head circumference was greater than the mean value by more than +2 S.D. The relatively large head is of particular interest as the same finding was described by Kirchhoff and Schaefer (1954) as being characteristic of the type of hypopituitary dwarfs of normal birth weight and without a space-occupying lesion.

It is well known that in dizygotic twins one placenta may be inadequate and that this results in a marked difference in size between the twins, but even undernutrition of this type would not produce pituitary deficiency. It is unfortunate that in neither Case 3 nor Case 8 was it possible to evaluate pituitary function more precisely.

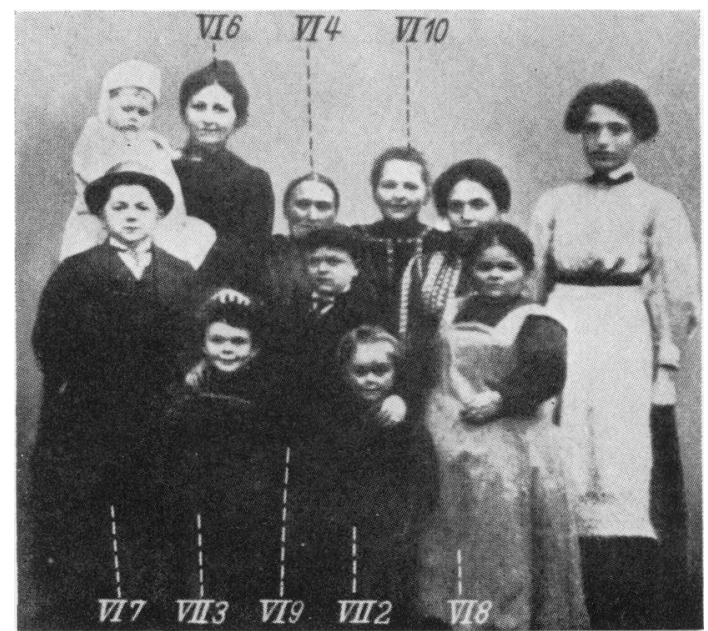

FIG. 9.-Snub-nosed dwarfism; recessive type: The family described by Verschuer and Conradi, showing Case 6 as 'VII 2'.
Possible Mechanisms. From the preceding descriptions it appears that low birth weight dwarfism can be divided into genetically and environmentally determined types. Such a classification gives no

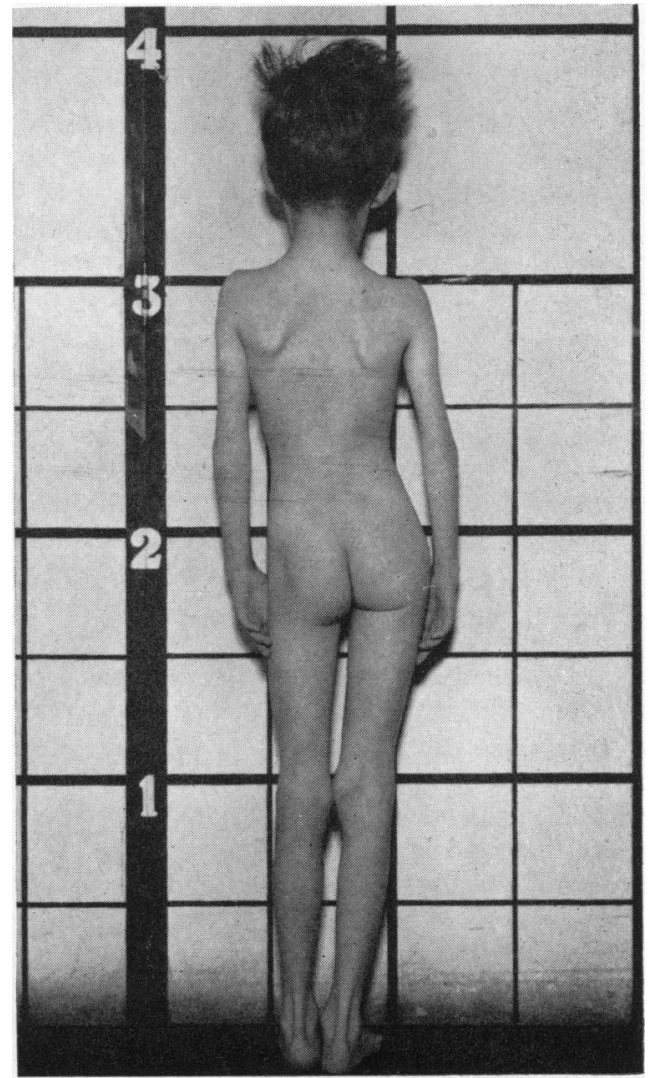

Fig. 10.-Russell-Silver type; probable placental disturbance in early pregnancy: Dr. A. Russell's case, showing asymmetry of trunk and relative shortness of left arm and leg (Case 8). 
clue to the immediate cause of the partial failure of growth. Even in genetically determined dwarfism the pituitary may be defective, as shown in the hereditarily dwarfed mice (Smith and MacDowell, 1930) and in the familial form of human pituitary dwarfism described by Hanhart (1953).

For dwarfism to be present before birth and to persist throughout life two possible mechanisms may be considered. Either some factor necessary for normal growth is lacking throughout the whole period, or some episode has occurred at an early stage in development, which has distorted permanently the pattern of growth to be taken by the cells of the body.

A deficiency of the pituitary is an obvious possibility, either panhypopituitarism or a deficiency of growth hormone alone. There is, however, considerable evidence that growth during foetal life and the immediate post-natal period is not affected by the absence of the pituitary. Thus, Kirchhoff and Schaefer (1954) state that in hypopituitary dwarfs without space-occupying lesions the slowing down in growth rarely occurs until well into the first year of life, and in hereditary dwarf mice growth proceeds normally until weaning (Smith and MacDowell, 1930). In rats which are born in a less mature state than humans, Walker, Simpson, Asling and Evans (1950) showed that hypophysectomy during the first 30 days of post-natal life had little effect on growth, but that a slowing down of growth occurred after $\mathbf{3 0}$ days. It has also been suggested that in the human foetus the pituitary is unnecessary for intra-uterine growth because infants born with complete absence of the pituitary are of normal weight (Reid, 1960). In the face of such evidence the findings in Case 3 and in LoPresti's case (Case 8, Table 5) are extremely difficult to interpret.

That factors other than the pituitary can permanently affect the pattern of growth has been shown by Widdowson and McCance (1960) who found that different levels of nutrition in the normal newborn piglet could modify the final size of the adult pig. It is therefore necessary to consider what non-endocrine factors might cause a permanently distorted growth pattern. Silver et al. (1953), Silver (1959) and Russell (1954) suggested that some disturbance in placental function had occurred in their cases at a very early stage in pregnancy. Seckel showed that in his Case 1 the erythrocytes, leucocytes and the epidermal cells were all normal in size, and he therefore suggested a slowing down in the rate of division of cells, from a very early stage, resulting in a reduction in the total cell mass.

\section{Conclusion}

In this paper an attempt has been made to show that low birth weight dwarfism consists of a number of separate clinical entities. It is hoped that the suggested classification may help in the further investigation of the problem.

I would like to thank Professor Stanley Graham for his advice and for his help in the investigation of the three cases, Dr. Alex Russell for kindly allowing me to publish the description of his case, and Dr. J. M. Tanner for his help in the preparation of the paper. I also acknowledge the kind permission given by Professor Doktor Freiherr von Verschuer, Springer-Verlag, Heidelberg, and Masson et Compagnie, to reproduce the photographs which appear as Figs. 6, 7, 8 and 9.

\section{REFERENCES}

Brissaud, E. (1897). De l'infantilisme myxoedémateux. N. Iconogr. Salpêt., 10, 240.

Dann, M., Levine, S. Z. and New, E. V. (1958). The development of prematurely born children with birth weights or minimal postnatal weights of 1,000 grams or less. Pediatrics, 22, 1037.

Drillien, C. M. (1957). Social and economic factors affecting the incidence of premature birth. J. Obstet. Gynac. Brit. Emp., 64, 161.

(1958). Growth and development in a group of children of very low birth weight. Arch. Dis. Childh., 33, 10.

Dutton, R. L. (1932). Apparatus for the micro-estimation of blood cholesterol. Lancet, 2, 787.

Falkner, F. (1958). Some physical measurements in the first three years of life. Arch. Dis. Childh., 33, 1.

Gilford, H. (1904). Ateleiosis and progeria: Continuous youth and premature old age. Brit. med. J., 2, 914.

(1911). The Disorders of Post-natal Growth and Development, p. 596. Adlard and Son, Bartholomew Press, London.

Hanhart, E. (1953). Die Rolle der Erbfaktoren bei den Störungen des Wachstums. Schweiz, med. Wschr., 83, 198.
Sie Rolle der Erbfaktoren bei

von Hansemann, D. (1902). Echte Nanosomie mit Demonstration eines Falles. Berl. klin. Wschr., 39, 1209.

Kirchhoff, H. W., Lehmann, W. and Schaefer, U. (1954). Klinische, erbbiologische und körperbauliche Untersuchungen bei primordialen Zwergen. Z. Kinderheilk., 75, 243.

prim Scher alter. Eine klinische und anthropologische Studie. Ibid., 75, 267 .

Lévi, E. (1908). Contribution à l'étude de l'infantilisme du type Lorain. N. Iconogr. Salpêt., 21, 297, 421.

(1910). Contribution à la connaissance de la microsomie essentielle hérédo-familiale. Ibid., 23, 522, 661 .

LoPresti, J. M., St. Martin, D. A. and Pascual, R. (1952). Hypopituitarism in infancy. Clin Proc Child. Hosp. (Wash.), 8, 188.

orain, P-J. (1871). Lettre préface à la thèse de Faneau de la Cour. Quoted by Lévi (1908).

MacIntyre, I. and Ralston, M. (1954). Direct determination of serum cholesterol. Biochem. J., 56 (Proceedings of the Biochemical Society, p. 43).

Provis, H. S. and Ellis, R. W. B. (1955). An anthropometric study of Edinburgh schoolchildren. Part I. Methods, data and assessment of maturity. Arch. Dis. Childh., 30, 328.

Ranke, $\mathbf{H}$. and von Voit, C. (1886). Über den amerikanischen Zwerg Frank Flynn genannt General Mite, dessen Körper- und Frank Flynn genannt General Mite, dessen Korper- und Graunschw., 16, 229.

Reid, J. D. (1960). Congenital absence of the pituitary gland. J. Pediat., 56, 658 .

Rischbieth, H. and Barrington, A. (1912). Treasury of Human Inheritance. Eugenics Laboratory Memoirs, Vol. 1, Section XVa. Dulau, London.

Rössle, R. (1924). Wachstum und Altern. Ergebn. allg. Path. path. Anat., 20(II), 369.

Russell, A. (1954). A syndrome of 'intra-uterine' dwarfism recognizable at birth with cranio-facial dysostosis, disproportionately short arms and other anomalies. Proc. roy. Soc. Med., 47, 1040.

Seckel, H. P. G. (1960). Bird-headed Dwarfs. Karger, Basle and New York.

Silver, H. K. (1959). Congenital asymmetry, short stature and elevated urinary gonadotropin. Amer. J. Dis. Child., 97, 768. , Kiyasu, W., George, J. and Deamer, W. C. (1953). Syndrome of congenital hemihypertrophy, shortness of stature and elevated urinary gonadotropins. Pediatrics, 12, 368. 
Smith, P. E. and MacDowell, E. C. (1930). An hereditary anteriorpituitary deficiency in the mouse. Anat. Rec., 46, 249.

Spence, A. W. (1953). Clinical Endocrinology, p. 495. Cassell, London.

Tanner, J. M. and Whitehouse, R. H. (1959). Printed for the Institute of Child Health, London, by Joseph Collard \& Sons, London.

Tompsett, S. L. (1949). The determination of the total neutral 17-ketosteroids in urine. J. clin. Path., 2, 126.

Troen, P. and Blumberg, M. S. (1948). Dwarfism of undetermined etiology. J. Pediat., 33, 591.

von Verschuer, O. and Conradi, L. (1938). Eine Sippe mit rezessiv erblichem primordialem Zwergwuchs. Z. KonstLehre, 22, 261.
Virchow, R. (1892). Vorstellung des Knaben Dobos Janos. Berl. klin. Wschr., $29,517$.

Vogt, E. C. and Vickers, V. S. (1938). Osseous growth and development. Radiology, 31, 441 .

Walker, D. G., Simpson, M. E., Asling, C. W. and Evans, H. M. (1950). Growth and differentiation in the rat following hypophysectomy at 6 days of age. Anat. Rec., 106, 539.

Widdowson, E. M. and McCance, R. A. (i960). Some effects of accelerating growth. I. General somatic development. Proc. roy. Soc., Ser. B, 152, 188.

Wilkins, L. (1957). The Diagnosis and Treatment of Endocrine Disorders in Childhood and Adolescence, 2nd ed., pp. 191 and 232. Charles C. Thomas, Springfield, Illinois.

\section{APPENDIX}

Summaries of case histories of reference cases taken from the literature.

Case 4 (Lévi, 1910; Case 1, Figs. 6 and 7). Born at term. 'It appeared that right from birth, his parents had been struck by his extremely small size.' Development throughout infancy and childhood was normal and he appeared to be of normal intelligence. Axillary and pubic hair appeared at 14 years and puberty proceeded normally. His right testis was rather high in the scrotum, though easily palpable, and both testes were normal in size. The terminal phalanges of his fingers were drum-stick shaped. Radiographic examination of his skeleton showed no abnormality.

He married at 20 years a woman of average height. There were two children, both very small at birth. The first (Lévi, 1910; Case 2) is described below (Case 5) and the second died at the age of 10 years.

Case 5 (Lévi, 1910; Case 2, Figs. 6 and 7). The first child of Case 4. He was extremely small at birth. He developed normally during infancy and childhood, but when examined at $12 \frac{1}{2}$ years he showed no evidence of puberty and neither testis was palpable. He appeared to be of above average intelligence. Radiographic examination showed a normal skeletal development (Lévi, 1910; p. 679) and no abnormality. In this family there were no known affected relatives in the parents' ancestry.

Case 6 (von Verschuer and Conradi, 1938; Case VII, 2). The authors state that 'she seemed from birth onwards to be unusually small'. She was thought to be of low mentality, but had had practically no schooling. Her periods started at 18 years. She had a termination of pregnancy and a few years later another pregnancy was terminated and she was sterilized. Radiography showed no abnormality of her skeleton. The family tree showed six dwarfs occurring in three generations; there were three males and three females. In each of the three affected sibships the parents were normal.

Case 7 (Fig. 10). (History and clinical details kindly supplied by Dr. A. Russell.) A male child, born weigh- ing $3 \mathrm{lb}$. $(1 \cdot 36 \mathrm{~kg}$.) and after a full-term pregnancy; during the sixth week of pregnancy the mother had 'influenza' and a brownish discharge. Apart from his small size at birth the only abnormality noted was a penile hypospadias.

At the age of 5 years 7 months he was seen by Dr. Russell on account of growth failure. He weighed $22 \mathrm{lb}$. $(10 \cdot 0 \mathrm{~kg}$.) $(<3$ rd percentile), his height was $37 \mathrm{in}$. $(93 \mathrm{~cm}$.) (<3rd percentile) and his head circumference was $197 \mathrm{7}$ in. $(50 \mathrm{~cm}$.). It was noted at this time that the arm and leg on the left side were shorter than on the right side. He was investigated for evidence of endocrine dysfunction, but the only abnormality found was an abnormal glucose curve with a low fasting blood sugar $(15 \mathrm{mg}$. per $100 \mathrm{ml}$.) and low figures at three hours (48 mg./100 ml.) and five hours (39 mg./100 ml.). When repeated at the age of 9 years 5 months the glucose curve was normal. Blood chemistry (apart from a slightly raised serum calcium of $11.6 \mathrm{mg} . / 100 \mathrm{ml}$. on one occasion, later normal) was normal and tests of adrenal and thyroid function were normal. At the age of 9 years 6 months no gonadotrophins were detected in the urine. Skeletal age as assessed by radiography of the carpus was consistently less than the chronological age (at 8 years, skeletal age was 5 years).

From the age of 7 years he was treated with intermittent courses of androstalone, with little apparent result until the age of $9 \frac{1}{2}$ years when an acceleration of growth and weight gain occurred. There was no history of dwarfism in the family, a younger sister was normal in height and the height of the mother was $5 \mathrm{ft} .4$ in. $(160 \mathrm{~cm}$.) and of the father $5 \mathrm{ft} .8 \mathrm{in}$. $(170 \mathrm{~cm}$.).

Case 8 (LoPresti et al., 1952). The second born of twins after a normal delivery. There was a slow gain in weight with several febrile episodes. Mental and physical development was very slow. Investigations showed normal serum electrolytes and blood urea. Radiography showed extreme delay in the appearance of ossification centres. The ventricular system was shown to be normal by pneumoencephalography, but there was the appearance of excessive air over the right hemisphere. There was an increased sensitivity to insulin. 